JOURNAL OF SECURITY AND SUSTAINABILITY ISSUES

ISSN 2029-7017 print/ISSN 2029-7025 online

2018 December Volume 8 Number 2

https://doi.org/10.9770/jssi.2018.8.2(6)

\title{
Scopus
}

\section{FAILED UNION: UNFULFILLED POTENTIAL OF THE EU'S UNION FOR THE MEDITERRANEAN}

\author{
Sima Rakutienè ${ }^{1}$, Roberta Paškevičiūtė ${ }^{2}$ \\ ${ }^{1,2}$ Faculty of Political science and diplomacy, Vytautas Magnus University, \\ V. Putvinskis st. 23 - 606, Kaunas LT-44243, Lithuania \\ E.mail: sima.rakutiene@vdu.lt ; paskeviciute.roberta@gmail.com²
}

Received 10 July 2018; 20 November 2018; published 30 December 2018

\begin{abstract}
Recent migration and other security crisis have made the Middle East and North Africa (MENA) region one of the most problematic and challenging for Europe. The lack of effective decisions to solve it raises the question, weather EU has ever had any good strategy for the relations with this region. This article examines the path of "Euro-Med partnerships" and the recent developments within the EU's external policy titled "Union for the Mediterranean". Since 1995, when "Barcelona process" was established, the European Union has been developing economic and political relations with the Mediterranean countries in North Africa and Middle East (MENA) region. Within this period EU has introduced several initiatives focused on the same region including "Barcelona process"/ "Euro- Mediterranean Partnership", "European neighborhood policy" and the newest one- the Union for the Mediterranean. Nevertheless, the results of the policies are far from satisfying the initial goals. Various institutional structures, which have been established for building the partnership, did not contribute much for settling the recent migration and asylum crisis in the EU either. This article analyzes the reasons and the main institutional frameworks paying attention on the goals' set and comparing it with the achievements of the EU policies in MENA region. It is stated that EU stance is rather based on "low politics" issues leaving aside the "high politics" questions for many years. We argue that the EU's external policies directed towards the Mediterranean region, namely the Union for Mediterranean (UfM), did not live up to its expectations and is more focused on low politics, topic-specific issues, rather than solving the major political challenges of the Mediterranean region.
\end{abstract}

Keywords: Euro-Med partnership; Union for Mediterranean; EU's foreign policy; institutionalism; international partnership; external governance

Reference to this paper should be made as follows: Rakutienè, S.; Paškevičiūtè, R. 2018. Failed union: unfulfilled potential of the EU's union for the Mediterranean, Journal of Security and Sustainability Issues 8(2): 181-197.

https://doi.org/10.9770/jssi.2018.8.2(6)

JEL Codes: F01

\section{Introduction}

Since 2002, when Ian Manners introduced the notion, that Europe is a normative power, many studies have examined EU's normative tools and impact on the third countries, the ones that are not members of the European Union. This interpretation of the EU, as being a normative power, also has clarified EU role in international affairs. However, the actual normative, institutional impact (whereas EU was able to change socio-political system) has not been frequent, and is in decline recently, even within EU's enlargement policy (which is considered as the most effective EU's external policy). This article is focuses on EU relations with MENA countries and searches for some normative impact EU has declared a desire to make.

In 1995 the first Euro-M-editerranean Conference started "a deeper and wider" co-operation processes between 
Europe and the Mediterranean region on a rather more formal level. The partnership also known as the Barcelona Process was the starting point for institutional structures creation and raised awareness as well as recognition of the importance of the relations for both regions and the sea which unites Europe, North Africa and the Middle East (IEMED, 2015).

Later, however, the Barcelona Process was changed into Union for Mediterranean in order to suit better for new challenges occurring in both regions and to comply more effectively with all the objectives the process has established. Thus, the initiative of French president Nicolas Sarkozy of launching Union for Mediterranean was pushed forward in 2008 in Paris, suggesting a new way for Euro-Mediterranean relations (Schlumberger, 2011). Therefore, the model of the Euro-Med policies has been constantly changing since its first appearance in the field seeking to fulfill new needs of the partners and solve the arising issues as effective as possible. However, the multilateral framework of the cooperation with Mediterranean region did not seem to have been prepared to properly correspond for the turbulence of the Arab Spring that went from state to state like a wave (in 2011), nor it helps to tackle undergoing migration and refugee crisis. So, is it failing? What kind of aims and strategic approach has EU been adjusting towards MENA region during all these years since 1995?

The goal of this article is to investigate and compare the different stages of EU's policies towards the MENA region and find out the impact of these Euro-Mediterranean partnerships' by using the qualitative analysis and secondary quantitative data analysis method.

We argue that the EU's external policies directed towards the Mediterranean region, namely the Union for Mediterranean, did not live up to its expectations and is more focused on low politics and topic-specific issues rather than solving the major political challenges of the Mediterranean region.

The new institutionalism theory, mainly historical institutionalism, was selected for the policy analysis and reasoning. "Path dependency", one of the mostly used concepts by institutionalists, helped to structure the analysis of policy evolution and find the existing gap between the official policy declaration and the real impact of the policy results.

\section{Methodology}

The paper is based on the social research qualitative methodology that involves several methods. Acomprehensive review of journal articles and other relevant literature was performed. One of the essential methods for the empirical analysis was the document analysis. This analysis includes all the main legal and other EU documents, as well as country progress reports, multilateral and bilateral meetings' declarations and agreements between the European Union and the non-EU Mediterranean Countries, Barcelona Process documents and Union for the Mediterranean programmes, communications, press releases, annual and other kind of reports together with other relevant documents. The documents' analysis was tremendously important for finding out EU's aims, seeking, approaches and making comparisons of different stages of the EU's policies towards MENA region. Furthermore, the progress reports or other EU policy review documents also highlighted the achievements and challenges of the relations.

In order to find out and compare the impact of the EU policies on different countries the secondary quantitative data analysis was performed by comparing mostly statistical data (e.g. Transparency International, Freedom House, Eurostat, The economist intelligence unit; Kisel'áková et al. 2018) of different time periods. The statistical data analysis involves the period since 1995 (although some statistical data is available just from 1998), when EU started the policy implementation of Barcelona process. As EU has attempted to make a normative or institutional change within socio-political systems of MENA countries, also to boom economic cooperationseveral criteria are taken into account: Firstly, political criteria (the scores of political rights, civil liberties, human rights, also democracy and political participation) were taken from Freedom House international worldwide trusted organization, that is conducting worldwide annual surveys. It is important to look at the dynamics of these scores in MENA countries and link it to the EU's policy goals (related to the transportation of norms 
and values- democracy, rule of law, human rights). The scores of the corruption or transparency levels in MENA countries were taken from Transparency International, also worldwide organization making annual surveys around the globe. So, by doing this statistical analysis we search for the trends- weather MENA region positively developed, is there any positive trajectory (gradual positive development) concerning the political dimension (having political systems more democratic). This trend has become even more important after 2004, European neighborhood policy implementation, when EU started to require more political reforms in exchange for more financing ("more for more" strategy implementation). So, following the logic of this strategy it is expected that Euro-Med partners gradually improved the democratic governance, but did these partner countries gradually reform the political systems and have better governance and democracy outcomes actually? Secondly, economic criteria, such as - exports and imports- show the level of economic cooperation with EU. The analysis of this statistical data, mainly taken from Eurostat, is linked to economic goals' implementation of these Euro-med partnerships. Has economic cooperation intensified? Did EU manage to reach a goal- to create a common free trade zone? The human development indexes also are analyzed as it reflects the development of the society and is closely tied to economic development aims. Thus, following the goals set in euro-med partnerships it is expected for the gradual positive human development and booming of economic relations with the EU, but did it happen in fact? The statistical data was collected about all the countries (EU partners) that participate in the Union for Mediterranean.

Finally, a semi-structured interview method was also used for the research, as additional qualitative method, supplementing the analysis. The invitations for the interview and the primary questioner were sent for officials and experts working in euro-med partnership field or having a high expertise in this field. As an outcome, the materials of 4 qualitative semi-structured interviews were conducted either in a personal meeting or via phone call. The interviews were made in Vilnius, March 2018 with representatives from Ministry of Foreign Affairs of the Republic of Lithuania and European Commission Representation in Lithuania. The other interviews via phone calls were conducted in March 2018 with representative of the Delegation of the European Parliament to the Parliamentary Assembly of the Union for the Mediterranean and a member of European Parliament, representing Lithuania. All the respondents of the interviews requested to grant discretion, thus their names will not be revealed. The selection of the respondents was mainly based on their expertise and work nature. The aim of the interviews was to investigate the respondents' view on EU politics towards MENA region, its effectiveness, results and problems. The average time of the interviews was 40 minutes.

\section{Institutionalism and "path dependency" within Mediterranean partnerships}

One of the most visible development or relative achievement the Euro-Mediterranean partnerships have produced for inter-regional relations is the establishment of various co-chaired institutions, multi-level frameworks, secretariat, parliamentary assembly and civil society forums. These institutional settings, as it were hoped by the diplomats and politicians, should have brought some diplomatic and institutional change in the regions very close to Europe. This process of the international institutionalization within Euro-Med partnerships is also tied to the reproduction of institutions and mode of governance produced by the European integration.

\subsection{Historical institutionalism and reasons for institutional change}

The historical branch of the new institutionalism is believed to have emerged reacting to the behaviouralist ideas (Lecours, 2005). This perspective leaves actors with more space to decide upon policies more individually while still operating in between the institutional context and its constrains. Rather than focusing on utility maximization, historical institutionalists grant institutions the role of shaping individual policy choices in terms of constraints placed on individual actors (Tolvaišis, 2012). Such features of the new institutionalism like pathdependency and critical junctures allow institutionalists to explain and analyze the effect of the institutions over time and occurrence of the institutional change. In explaining the institutional change, historical institutionalists focus on timing and sequences (Lecours, 2005).

The reasons for institutional change, as Mark Pollack provides, might be very different. The change is usually 
influenced by the changes in the policy environment, or by the change of the actors or in their relative powers, also by improvement in the quality of information (Pollack, 1996). Therefore, conscious decisions about new structures, practices or rules shapes the institutional change. And the likeliness of an institutional change is mostly predictable when the interests of those who seek change are stronger than those who serve for the current arrangements in the institution (Gorges, 2001).

But the change (especially if we mind political change) is usually coming very slowly and according to Thomas Koelbe, the question of how we do explain the things people do, is the core in social sciences (Koelble, 1995). Theories of the new institutionalism are relevant to explain it. Recently institutions have become larger, more complex and resourceful and because their importance to collective life is now greater than ever before, it is essential to speak about institutional impact (March, Olsen, 1984).

One of the key concepts historical institutionalists use, when explaining institutional development, is "path dependency". The idea of path dependency is related to the causal relevance of the preceding stages and in temporal sequence of the specific institution (Pierson, 2000). Or in other words, path dependency argues that when institution is established, it starts its own life and individually might direct political processes. Institutions then gain logic of their own what leads to the unplanned and unpredictable developments and consequences unforeseen by actors (Lecours, 2005). Therefore, the assumption of actors not being fully aware of the results of their choices at a particular time will eventually come out as their future behaviour and the future actions most probably will be constrains by the decisions made in the past which would be difficult to reverse (CIVITAS, 2015). Historical institutionalism is widely used to explain European integration and it's outcomeinstitutionalism, that the integration process has produced, including the consequences and the gained power by the established institutions (Pierson, 1994) Naturally, it also could be helpful in explaining the international institutionalism promoted and established by the EU but outside the EU.

Despite the opinion that institutions are difficult to change due to their embeddedness, stability and path dependency, some historical institutionalists argue that institutions change when facing new problems and times of crises. Crisis allows the institutional change acting through giving the leaders the opportunity to set forward new plans and ideas and to plant them in the institutional framework. The historical institutionalists tend to divide the history into periods of normal and critical from which the latter one is given the possibility of a major institutional change (Gorges, 2001). Thus, the feature of the critical junctures allows the explanation of the institutional transformation.

Further following the logic of the idea of institutional change from the new institutionalism point of view, the slow and imperfect adaptation and rather change-resistant process could be also explained by the slow modernization of the Mediterranean region countries if to compare it with the processes in EU and Europe in general, thus, impeding the EMP and later the UfM to move forward. This was also revealed during an interview with a member of the European Parliament:

"In most of the cases the documents, signed agreements and other formalities might seem like a big step forward, however, in real life it is very doubtful whether anyone has enough political will to start engaging in deep cooperation and rising high requirement for, first of all, good governance and proper governmental institutions in the Mediterranean countries. And here we have a paradox that the closest neighbor for these countries is Europe with the European Union while they still continue to live by the traditions and perceptions of the $19^{\text {th }}$ century." (Interview with a Member of European Parliament, Lithuanian representative)

Historical institutionalism explains that the institutional change and transformation occur due to the exogenous shocks. Such international events like wars or international economic crises affect not only the domestic matters of a state but interrupt the cycle of institutional processes and reproduction leading to opening up for institutional transformation and change opportunities (Lecours, 2005). In the EMP case, the main shocks could be named as the conflicts in the Middle East during the first decade of the $21^{\text {st }}$ century (disturbances and upheavals in countries like Palestine, Israel, Iran, Iraq, Syria, Lebanon (Al Jazeera, 2008), the rising concerns of the terrorism threats, especially after the 9/11 attacks or the global financial crises started in 2007 (Ross, 
2016). All these events had an impact on the functioning of the Barcelona Process and as it was stated by the EU, the Middle East conflicts and insufficient or even none economic growth required changes in the policies (COM 2008, 319).

\subsection{Comparing Euro-Med partnerships in the context of "path dependency"}

The "path" of the Euro-Med partnership, as an international institution to be established, started in 1995 and there were several causes behind this beginning. According to some analyst international factors such as the world economic crisis in 1970s that started the globalization process also had an influence. The Barcelona Process was supposed to affect the asymmetry in economic power and pursue the European hegemony in Mediterranean in order to strengthen the position of EU in the global economic competition (COM 2008, 319). Researchers also state that EU was seeking to create a pacific, stabilized and prosperous Mediterranean region by building a dynamic economy of liberal trade, increasing interdependence and globalization process fostering (Abis, Petiot, Semerari, 2015). The reshaping of the Mediterranean policies was also seen as EU's intention to balance the Eastern initiatives with the policies to the South as some of the Central and East European countries, from the point of view of Southern EU countries like France, Italy or Spain, was getting an exclusive attention at the expense of the South (Attina, 2004). Hence, the Mediterranean countries were expecting for more trade and aid from the EU to improve the situation in the region (Attina, 2004).

The co-operation between the EU and Mediterranean is expressed to be of a strategic importance and the general objective of the Barcelona Declaration is about making the Mediterranean into area of dialogue which could guarantee peace, stability and prosperity of the region based on a stronger democracy, deeper respect for human rights as well as sustainable economic and social development and a greater understanding between the partner countries cultures (Barcelona Declaration, 1995).

As Table 1 provides, the "path" of the EU relations with the Mediterranean could be divided into three periods. The first period - Barcelona process- started the formal cooperation on the multilateral level. However, meetings on foreign affairs ministers' level were not frequent and annual. It shows the low level of interactions and engagements as well as commitments to strengthen regional cooperation. The second period started in 2004, when European neighborhood policy (ENP) was initiated and the first Action plans were signed by the EU and individual partners. In comparison with the first period, ENP is focused on bilateral (EU - partner) relations with a seeking to promote political and socio-economic reforms in the partner country according to the ambitions and the level of approximation with EU law the specific partner wants. Finally, the third period gave the momentums with the establishment of the Union for Mediterranean and it is associated with the ambition and leadership of N. Sarkozy, French president at the time. This new, more institutionalized and co-ownership based, Union for the Mediterranean did not distance its objectives and goals far from the Barcelona Process and are based on the ones set in 1995. The difference though is that UfM started to focus on a more specific issues and spheres, directed towards a particular problem and obstacle in the region. Thus, it was decided upon six concrete action fields that will be in the focus of the practices of the UfM and should provide a basis for the sustainable development of all the Mediterranean region. 
Table 1. EU initiatives towards MENA region

\begin{tabular}{|c|c|c|c|}
\hline EU initiative & Barcelona process & European neighborhood policy & Union for the Mediterranean \\
\hline Year of establishment & 1995 & 2004 & 2008 \\
\hline Mode of relationship & $\begin{array}{l}\text { Multilateral, multilevel, } \\
\text { regionalism }\end{array}$ & $\begin{array}{l}\text { Bilateral, multi-level, EU-partner } \\
\text { based relationship }\end{array}$ & $\begin{array}{l}\text { Multilateral, multi-level, } \\
\text { regionalism }\end{array}$ \\
\hline Participating countries & $\begin{array}{l}\text { EU members, Algeria } \\
\text { Egypt, Israel, Jordan, Lebanon, } \\
\text { Morocco, Syria } \\
\text { Tunisia, Palestinian Authority, } \\
\text { Macedonia } \\
\text { Turkey }\end{array}$ & $\begin{array}{l}\text { EU members, Algeria, Egypt, } \\
\text { Israel, Jordan, Lebanon, } \\
\text { Morocco, Syria (not signed ENP } \\
\text { action plan), Tunisia, Palestinian } \\
\text { Authority, Libya (not signed } \\
\text { ENP action plan), Eastern } \\
\text { neighborhood countries }\end{array}$ & $\begin{array}{l}\text { EU members, Algeria, Albania, } \\
\text { Egypt, Israel, Jordan, Lebanon, } \\
\text { Morocco, Syria, Tunisia, Palestinian } \\
\text { Authority, Montenegro, Turkey }\end{array}$ \\
\hline $\begin{array}{l}\text { The main functioning in- } \\
\text { stitutions }\end{array}$ & $\begin{array}{l}\text { Meetings of foreign affairs } \\
\text { ministers, Euro- Med } \\
\text { committee, working groups, } \\
\text { parliamentary assembly, civil } \\
\text { society forum }\end{array}$ & $\begin{array}{l}\text { Association agreements, ENP } \\
\text { action plans }\end{array}$ & $\begin{array}{l}\text { Secretariat, co-presidency, Summit, } \\
\text { foreign affairs ministers' meetings, } \\
\text { sectoral ministers' meetings, } \\
\text { permanent joint committees, senior } \\
\text { officials meetings, Parliamentary } \\
\text { Assembly, regional and local } \\
\text { assembly, civil society forum. }\end{array}$ \\
\hline $\begin{array}{l}\text { Seekings / main areas of } \\
\text { cooperation }\end{array}$ & $\begin{array}{l}\text { Three dimensions: political } \\
\text { (peace, stability, human rights; } \\
\text { economic (free trade area), } \\
\text { cultural cooperation }\end{array}$ & $\begin{array}{l}\text { Social, political and economic } \\
\text { reforms in partner countries, } \\
\text { approximation with EU law and } \\
\text { standards }\end{array}$ & $\begin{array}{l}\text { Projects oriented partnerships ( } 40) \text {, } \\
6 \text { main fields of cooperation ( } 23 \\
\text { footnote) }\end{array}$ \\
\hline
\end{tabular}

Source: Created by the authors based on the documents' analysis

However, up to now, both initiatives- ENP and Union for the Mediterranean- coexist and are functioning. It is evident some overlapping of the goals and ideas but very specific, projects - oriented cooperation, is visible either. Prioritized areas had more than 40 projects being implemented in the spheres like business, employability, public services, education and research, social and civil affairs, energy and environmental matters.

The non-political sector-specified goals and initiatives after all raised some concerns and discussions of the Euro-Mediterranean relations experiencing a shift from high to low politics. There are some divided opinions whether the shift is visible. A representative of the Delegation of the EC for the UfM does not agree that the change between high and low politics is so visible, but he admits that the new organization at some point lost its essence: " $<\ldots>$ now most of discussions have lifted the UfM. $<\ldots>$ I think, the whole process has lost its momentum" (Interview with a representative of the Delegation of the European Commission for the UfM).

Another opinion supporting the argument that the shift is visible was expressed in another interview with a representative of the Lithuanian MFA: "If we look at the very beginning of the Barcelona Process, it was highly ambitious and now, looking at the UfM, it does not seem to extend as high as before. $<\ldots>$ and the change from high to low politics is visible here" (Interview with a representative of the Ministry of Foreign Affairs of Republic of Lithuania).

As regarding probably most of the EU polices, the division of opinions is a usual case, however, it is evident that on a declarative level the UfM is still a continuation of the Barcelona Process in the means of the goals and objectives, but the third period of the "Euro-Med partnership" path emphasized the prioritization of area and projects - oriented cooperation based more on sectoral policies than "high politics". The current situation appears to be a paradox between the expectations hoped at the beginning and the actual interest and institutional impact existing today. 


\section{Policies' impact on the political and economic developments of the MENA countries}

This part seeks to evaluate the Euro-Med partnerships' role in the region and to find out the existing conditions in the one of the most contested and problematic regions in the EU neighborhood. Therefore, the secondary quantitative data analysis was performed focusing on political and economic criteria. Thus, following the logic, values, goals and the whole Euro-Mediterranean relations development a kind of comparison between different times and periods have to be conducted, starting from the very beginning in 1995 and ending with the latest available data from around 2017 (however, the analysis strongly relies on the data available as some of the measures and criteria used do not date back as far as 1995). The political criteria and scores reflect the political dimension of Euro-Med partnership and is linked to the facilitation of socio-political reforms in MENA countries for seeking more democratic and better governance of their political systems that should guarantee the stability in the region.

However, an important point in time (2011-2012) of the Arab Spring (when civil revolutions in MENA countries insisted for political change) should be emphasized as important focal point as changes occurring in the region were of a great importance and these changes is more tied to internal politics than the impact of EU politics.

\subsection{Searching for political change}

As one of the most important and desired objectives that was raised in the Barcelona Declaration and later even more expressed in the European neighborhood policy was stability and prosperity of the region built on good governance, human and political rights, democracy, the data of the Freedom House was chosen, namely the ratings of the civil liberties, political rights and the over-all freedom rating. The data was collected in the period from 1998/9 up to 2017 every two years, except for the event of the Arab Spring which was about changing and reforming these fields. Therefore, the data of the year 2011 and 2012 were of a great importance.

The feature of the civil liberties rating takes into account such categories like freedom of expression and belief, associational and organizational rights, rule of law and personal and individual rights and the tendencies in the Mediterranean region regarding these criteria (Figure 1) do not set a positive background as in most of the countries the level of civil freedom is closer to the least free, for example, Algeria, Egypt, Jordan, Mauritania. The changes in Libya and Syria are rather upsetting due to the internal conflicts they were or still are experiencing. Even though some states like Israel or Montenegro seem to be on the right level of civil liberties or even regarding the evident positive changes in Lebanon, Morocco or Tunisia, the region still remains as one with the least civil liberties.

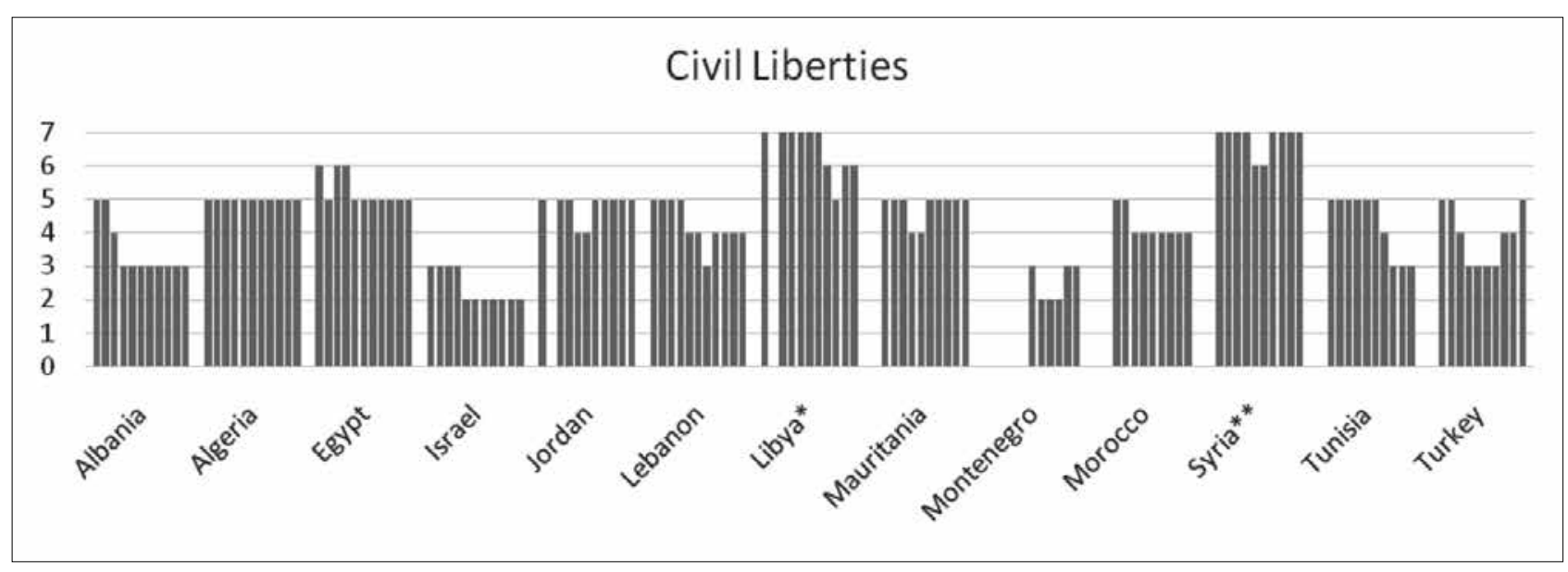

Figure 1. Civil Liberties from year 1998 to 2017 (1 - most free, 7 - least free), made by authors based on the Freedom House data 
The data evaluating the situation of the political rights considers the electoral process, political pluralism and participation and functioning of the government which were also one of the goals of the desired reforms leading to stability and prosperity of the neighborhood. However, as it is evident from Figure 2, the situation in this field has not lived up to the expectations as only in a few of the countries, Lebanon and Tunisia in particular, a positive change occurred since the establishment of the Barcelona Process. In most of the rest of the countries the positive improvements that were occurring were set back to previous or even worse level of the political rights. Thus, regarding the tendencies in the Mediterranean region, it can be stated that the objectives of the Euro-Mediterranean relations frameworks not only were not reached but rather alienated even furthered from the starting point.

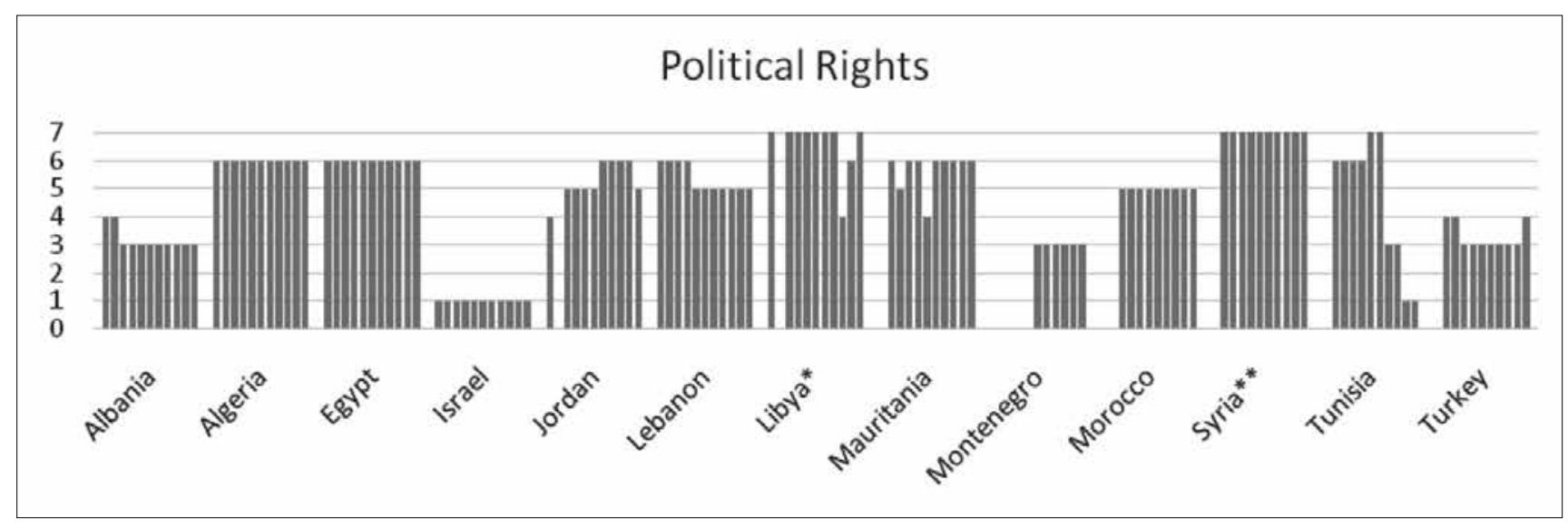

Figure 2. Political Rights from year 1998 to 2017 (1 - most free, 7 - least free), made by authors based on the Freedom House data

The general overview of the Mediterranean region countries from the point of freedom level (Figure 3) is still rather negative as only a few of the states actually managed to improve and steadily maintain that positive change up till these days, in particular Albania, Lebanon and Tunisia. However, the general tendency is still negative as most of the region did not improve and remain under the average level of least free rating, meaning that the political goals were not properly fulfilled.

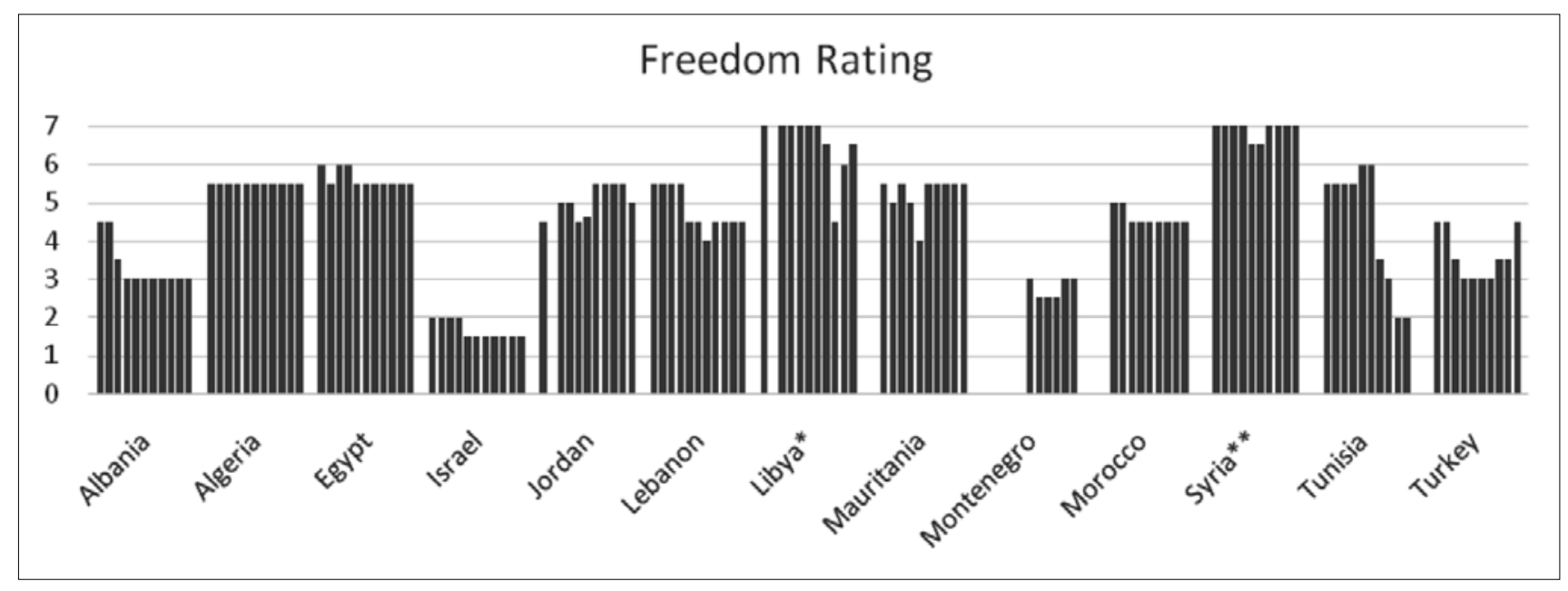

Figure 3. Freedom Rating from 1998 to 2017 (1 - most free, 7 - least free), made by authors based on the Freedom House data

If looking again to the values and goals of the Euro-Mediterranean relations frameworks, one of the fundamental key factors was the democratic way of life which the Mediterranean region was lacking at the very beginning. To evaluate the development of the democracy establishment in the region, the Democracy Index of the Economist Intelligence Unit were taken into account. Data was collected from 2006 to 2016 every two years in order to have a closer look at the situation in the region. There seem to be a general positive change (Figure 4) in the most recent times, however, too slow and hardly evident, thus, cannot be taken as completely positive in reaching 
set goals. Despite this, numerous countries seem to be experiencing a constant deterioration regarding the democracy level in the state, such as Egypt, Lebanon, Palestine or Syria. The only stable and rather democratic country of the region was Israel throughout all the period of collected data.

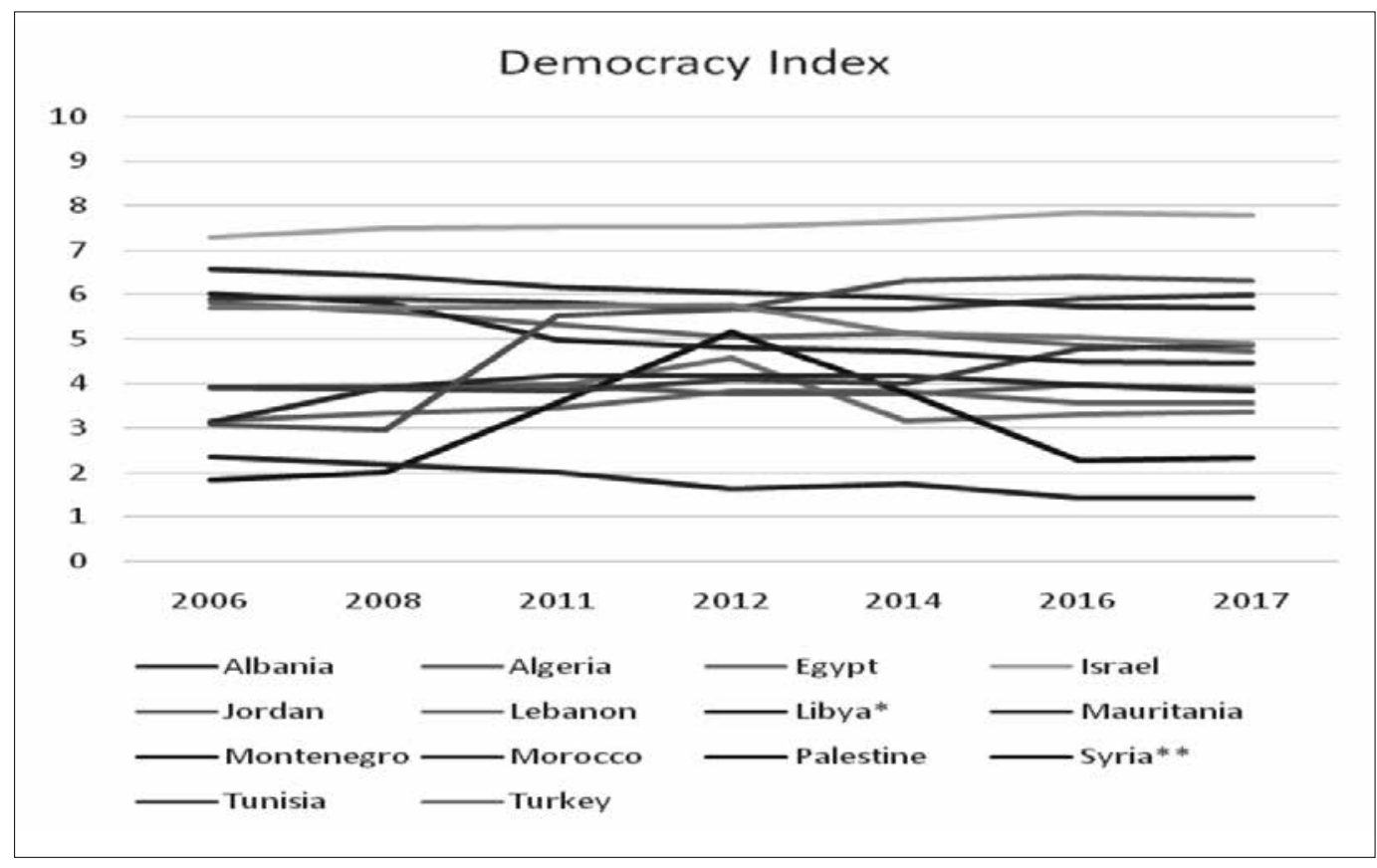

Figure 4. The Economist Intelligence Unit's Democracy Index, made by the authors

Thus, regarding the analysis based on the data from the Freedom House and The Economist Intelligence Unit, it could be summed up that the Mediterranean Partner Countries are in top of the least free and least democratic countries in the world, leaving both, the Barcelona Process and the UfM frameworks in rather not a meaningful role for over 23 years, regarding the political dimension and its objectives. Therefore, neither EU normative goals were achieved nor created institutions had any visible impact.

Another desired goal of the Euro-Mediterranean relations was to make the Mediterranean region more transparent, helping to eradicate huge corruption levels, thus, the data of Transparency International is of a fundamental importance to the current analysis. The data collected from this source was taken in the period of 1998-2017 (approx. every two years), however, it had to be separated in two parts as some measurement methodology of the Corruption Perception Index changed after 2011. Regarding the results of the Corruption Index, the Mediterranean region seems to be one of the least transparent from around the globe despite the Arab Spring that contained a lot of hope for positive changes (Hattar, 2017). The situation before 2011 was not developing positively as well since in most of the countries a rather deteriorating situation is evident with exceptions of Albania, Morocco and Turkey, although the changes are rather modest. 


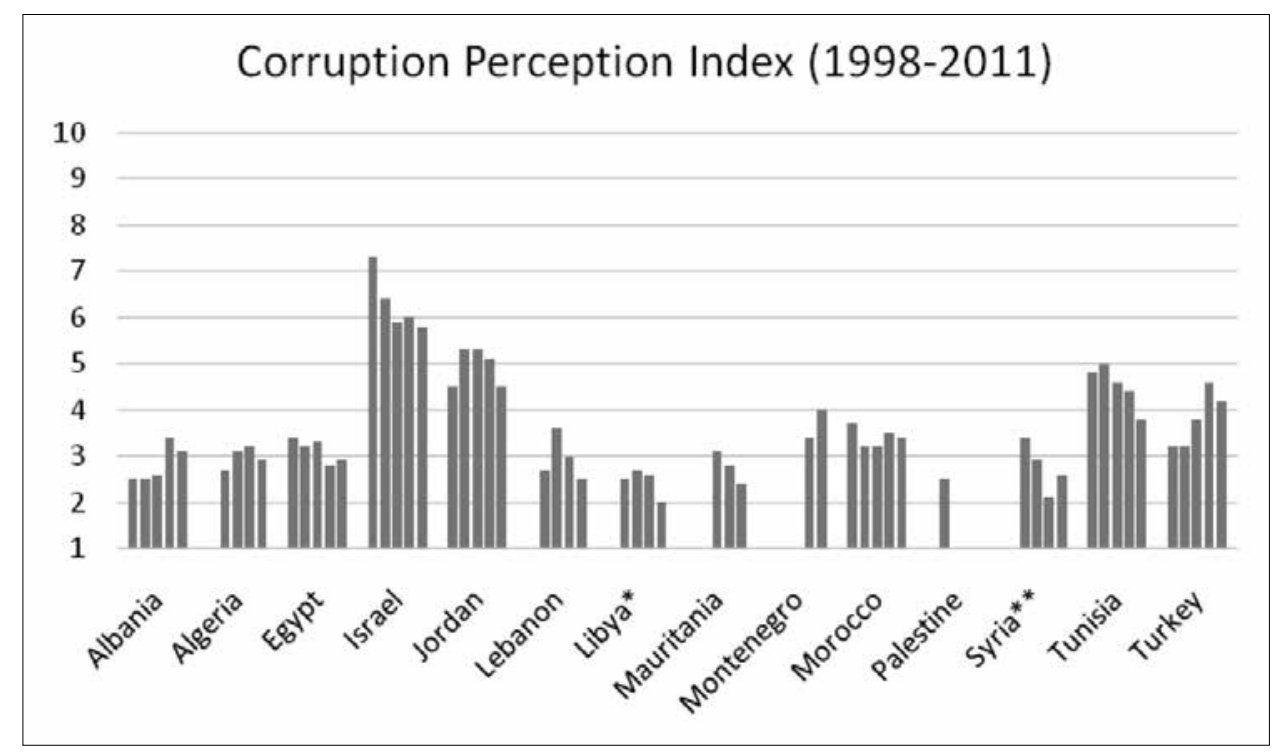

Figure 5. Corruption index 1998-2011 (0 - highly corrupt, 10 - highly transparent), made by the authors based on the Transparency International data

As it was discussed already, the Arab Spring did not bring as much changes as it was expected, especially regarding the corruption levels. As it is visible from the Corruption Perception Index (Figure 5, Figure 6), only one country, namely Israel, is positioned above the middle line of transparency and the remaining countries of the region do not show any significant changes in this field. Some improvements can be seen only in the case of Montenegro and very minor ones in the cases of Albania, Morocco and Tunisia, but the Balkan countries (Montenegro, Albania) even if involved into Union for Mediterranean have EU membership perspective and their positive trend is impacted more by accession and Europeanisation strategies, than Euro-Med partnerships.

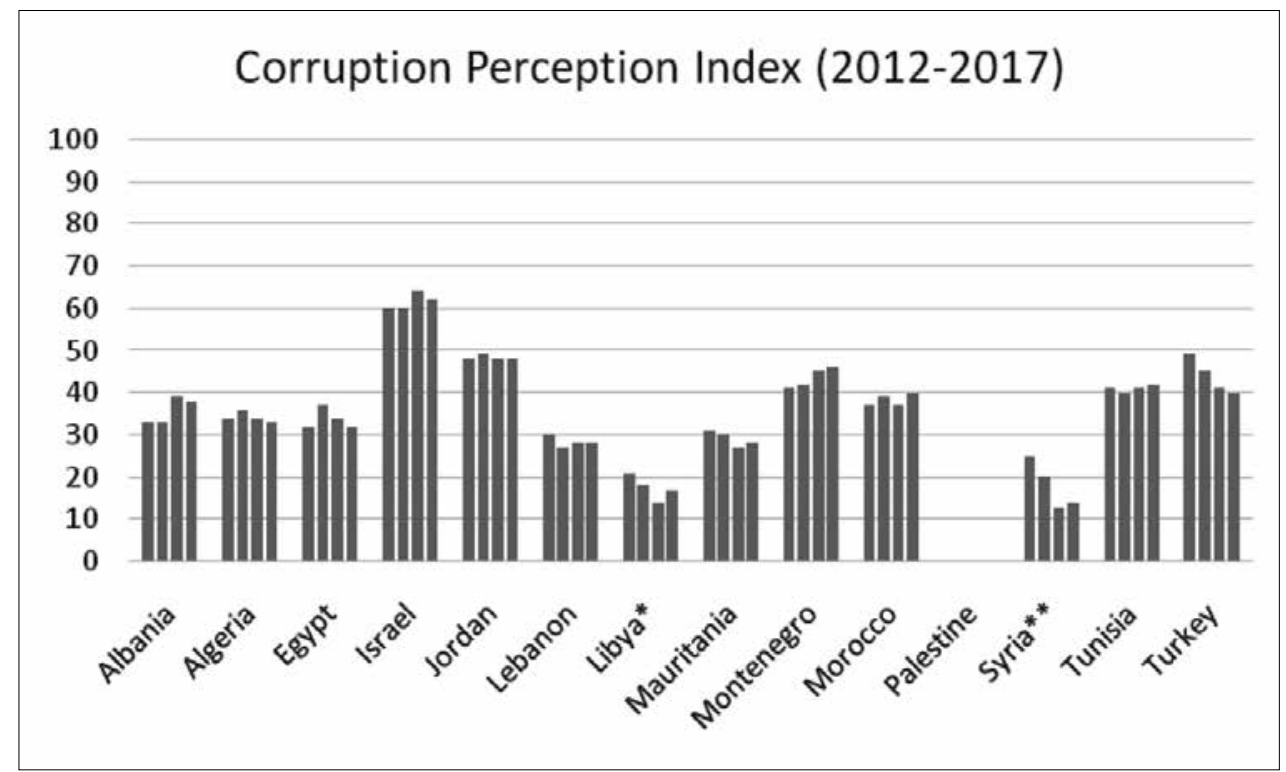

Figure 6. Corruption Perceptions Index 2012-2017 (0 - highly corrupt, 100 - highly transparent), made by the author based on the Transparency International data

Thus, regarding what was discussed above, it is evident that almost all MENA countries did not reach $50 \%$ of transparency, which means that they cannot cope with the corruption levels in their countries. Also, the figures show that some institutional change occurred for some years after Arab spring (Algeria, Egypt), but the process of institutional change stopped or even got negative trend recently. 


\subsection{Economic and human development}

To create the free trade area between EU and MENA regions has been one of the key objectives already set within the Barcelona Process and later the same idea has been part of the Union for Mediterranean. Thus, it is necessary to analyze the developments in trade cooperation. The importance of this field can be seen also in the number and frequency of the Trade ministerial meetings throughout the years (annual meetings between 20012010). As trade in goods is said to be of an overwhelming importance (Passerini, Biedma, 2002), the analysis of trade in this part will be focused on these criteria, however, it is important to note that the analysis conducted below is to show a rather general situation in the field of trade between the regions.

At the very beginning of the Barcelona Process, the amount of trade in goods between the EU and the Mediterranean Partner Countries (Figure 7, Figure 8) was rising and after the 1995 a higher growth rate is visible what could be explained by the establishment of the Barcelona Process and engagement in its activities.

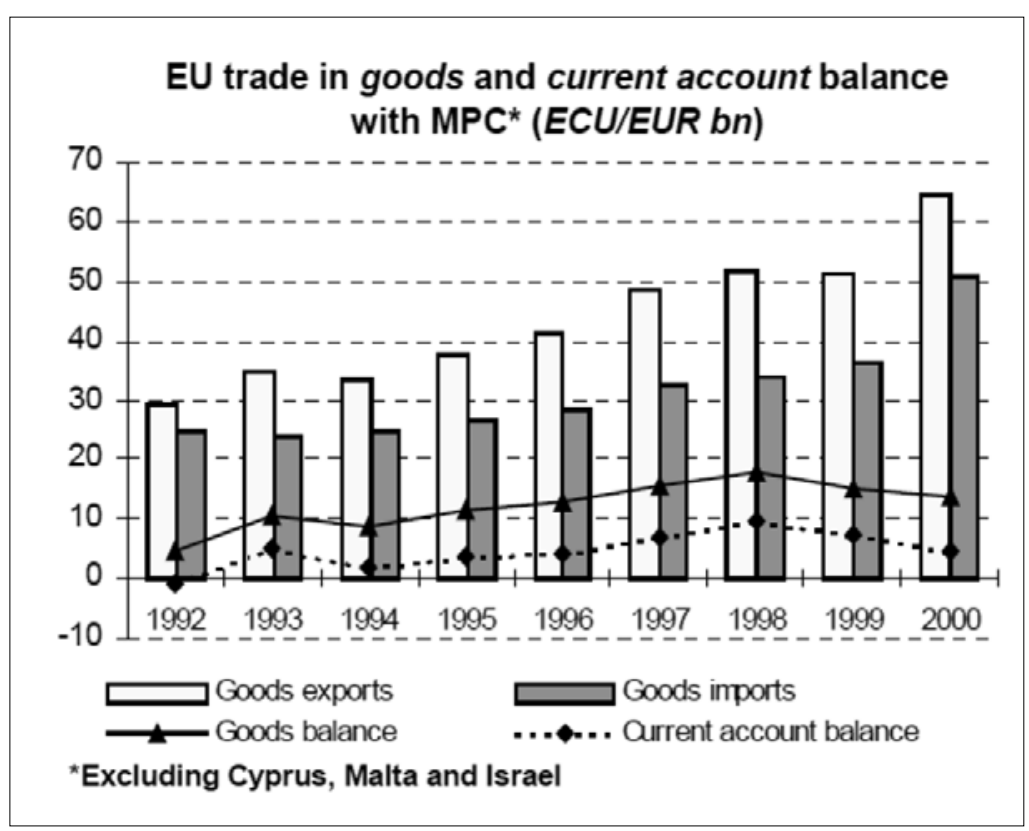

Figure 7. EU trade in goods with the MPC.

Source: Passerini, Biedma, 2002

However, there seem to be no significant growth in trade of goods except of some extreme changes in some countries like Libya or Syria of which deteriorated results could be explained not because of the failed or successful activities of UfM but rather because of the internal crisis that were already discussed. Turkish case is different because in comparison to other Mediterranean countries it has privileged relations with the EU, functioning Customs Union and membership perspective (even though for now it seems a frozen case).

If looking to the data from 2008, when the UfM framework came to force, a general view would be that no significant growth was reached. These rather negative results could be seen as both, the reasons and the outcomes of why the objective of the Euro-Mediterranean Free trade area was not reached by 2010 as expected. 


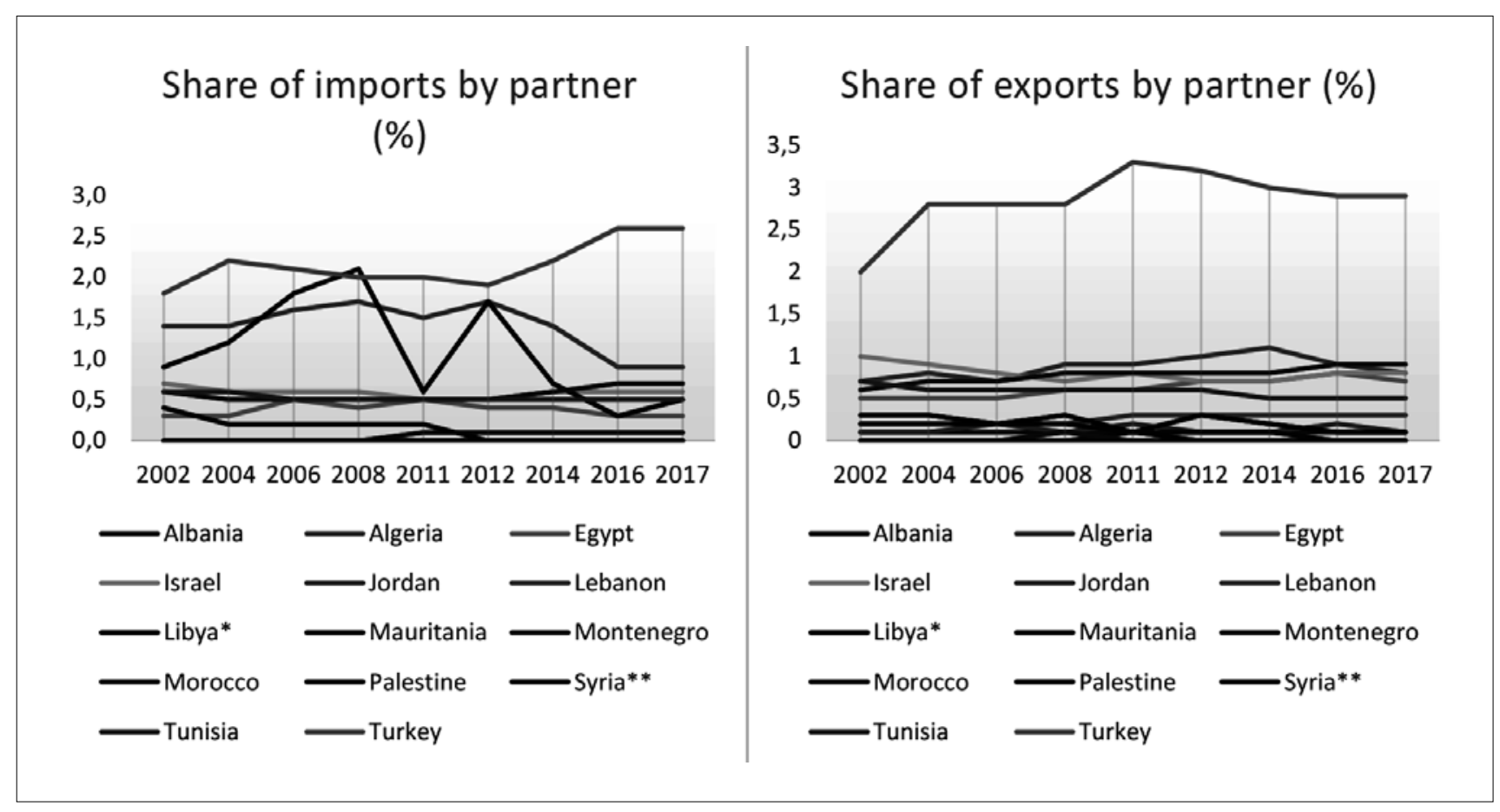

Figure 8. Extra-Euro trade area, share (\%) of imports and exports (made by authors based on the Eurostat data)

As the Free Trade Area appeared to be hardly achievable, even more attention was given to strengthening the South to South cooperation, as, according to the latest study of the Secretariat, only $1 \%$ of the trade flows in the region are between the Southern neighbors (UfM Roadmap for Action, 2017). The southern Mediterranean partners are still lacking regional cooperation in MENA region and the Euro-Med partnerships from the very beginning has seek to push for the multilateral cooperation. But even now after more than 20 years of multilateralism promotion towards this region it could be stated that the international institutionalism did not root in the region.

\subsection{Human development}

If going closer to a personal lifestyle and conditions of Mediterranean people to which a lot of attention was also given in setting the goals of the Euro-Mediterranean cooperation as it was supposed to encounter the everyday problems of every citizens what was seen as the root causes of regional instability and impediment for prosperity. Various data analysis and criteria exist to study these particular problems (e.g Radwan, 2018) but for the current study the Human Development Index which takes into consideration such dimensions like longevity and health of life, education and a descent standard of living was chosen (Human Development Report, 2015). Data was collected in the period of time between 1990 and 2015 as the annual data was not available. 


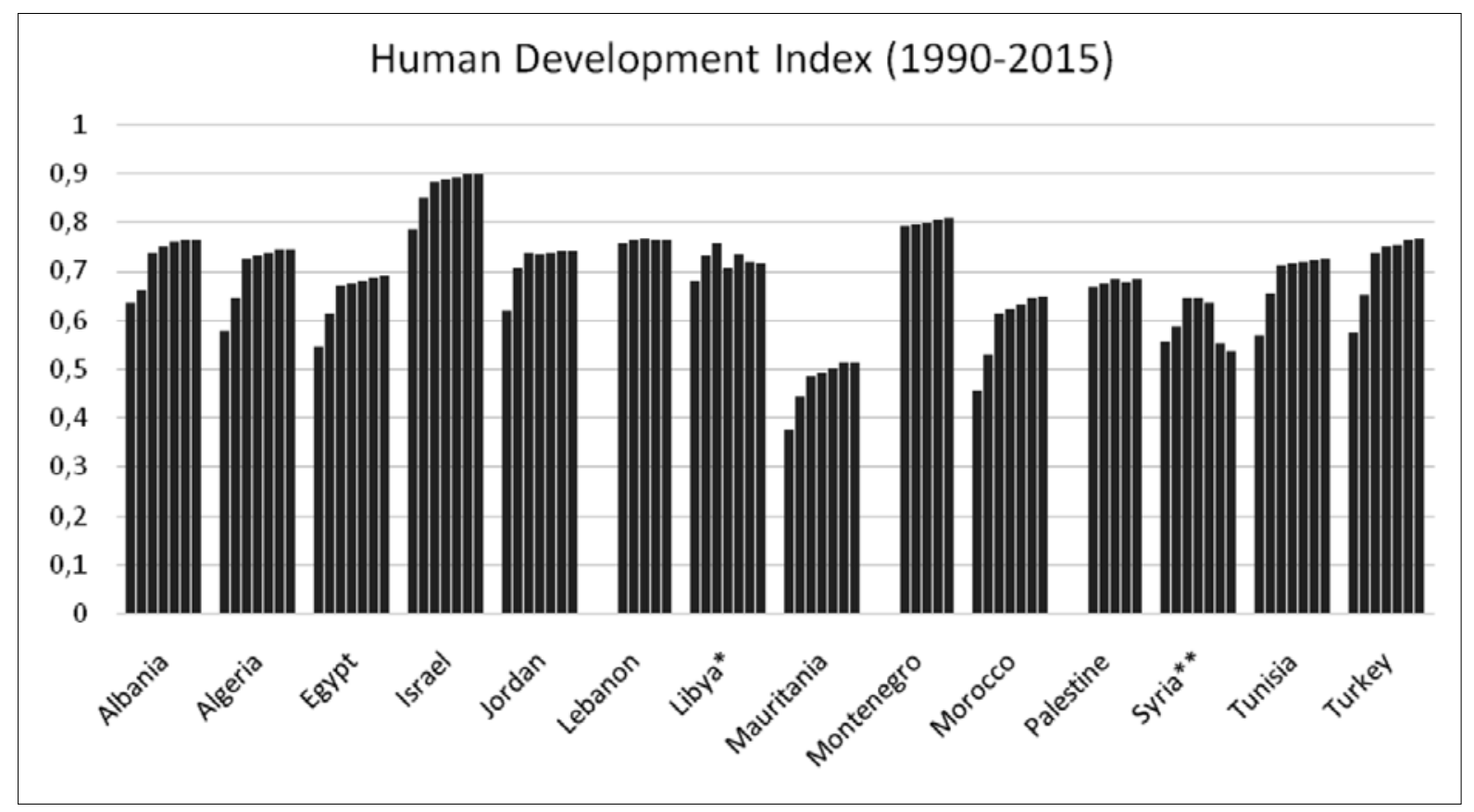

Figure 9. Human Development Index (1990-2015) (0 - very low development, 1 - very high development), made by the authors based on the UN data (Human Development Data (1995-2015)

The tendencies of human development in the Mediterranean are not as negative as it was observed analyzing other, rather political criteria. As it is evident form Figure 9, in all of the countries the situation of human development improved, however, with the exception of Syria as the country is living under the civil war conditions. Another important thing to note is that, regarding the Human Development index, most of the Mediterranean Partner countries, apart from Mauritania, remained above the average level and most of the countries position under the high human development category.

Based on the most recent UfM Road Map, adopted in the end of 2017, the activities of this framework have already reached first tangible impacts on the ground, if to be precise, 200000 individuals are said to have received the benefits of the 26 labelled projects in the fields of human development, youth employability and women empowerment. Another 21 projects were dedicated for sustainable development and all the projects in total were labelled to be worth more than 5 billion Euros (UfM Roadmap for Action, 2017).

Focusing on the tendencies of youth unemployment in the Mediterranean region (Figure 10) a general improvement can be visible between year 2005 and 2010, however, not highly significant, contrary to the change evident from 2011. A deteriorating situation in the countries did not reach the level of youth unemployment as, for example in the year 2000, nonetheless, the growing percentage of unemployed young people suggests that the initiatives of the UfM in this regard were not as successful as it was expected. On the other hand, it should be noted that the most important projects directed towards youth employment were labeled only after year 2013 (Med4Jobs, 2016), from which a minor improvement could be seen, although this growth cannot be granted as a successful implementation of the UfM initiatives yet. 


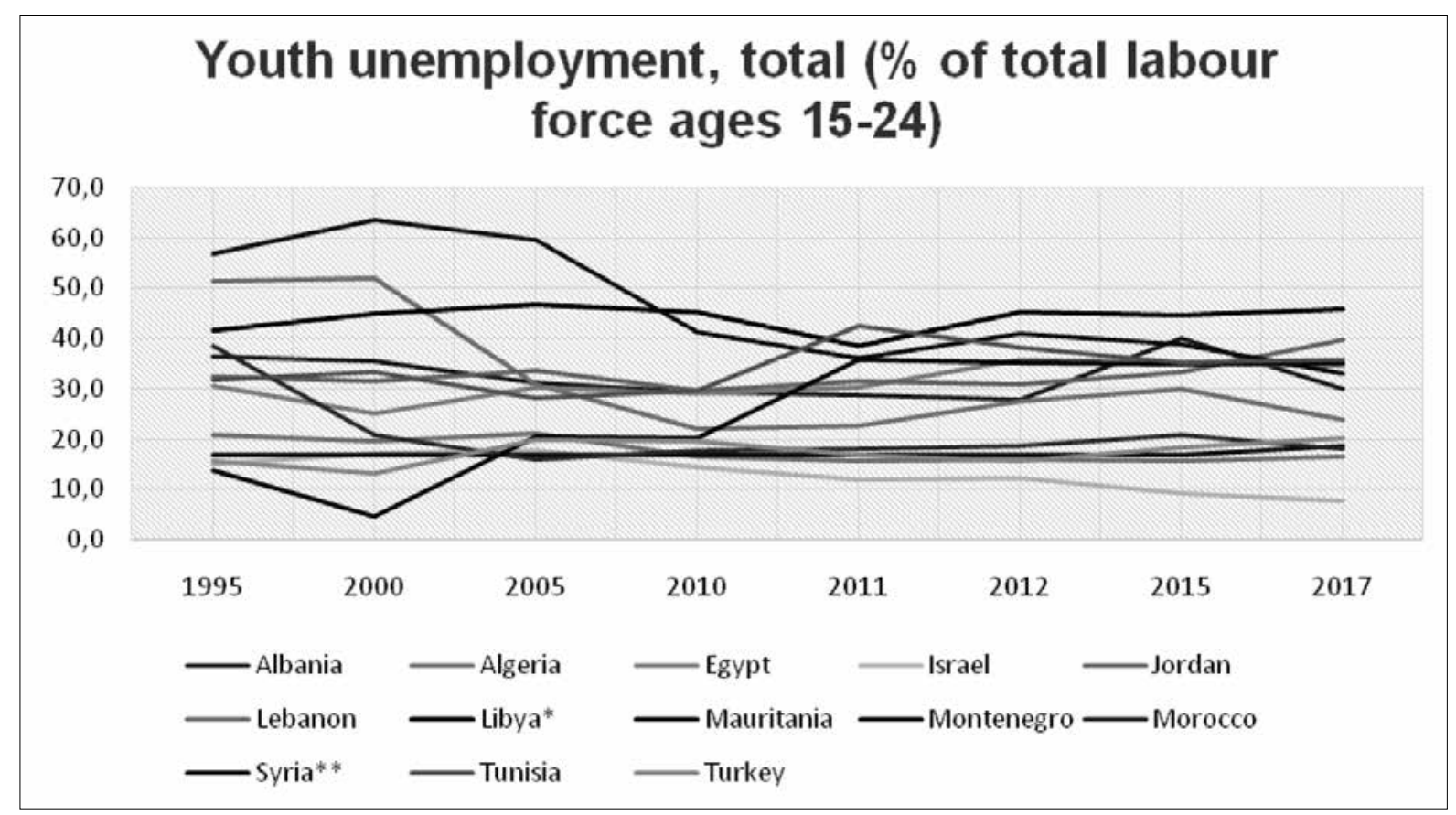

Figure 10. Youth unemployment, made by the authors based on the ILO data

Another key feature for the UfM and the Euro-Mediterranean relations in general, is the initiatives directed towards women empowerment and gender equality in the region. It was stated that all of the UfM member countries are strongly committed to this field, however, also noted that a considerable gap remains between the legislative efforts and actual implementation ( $4^{\text {th }}$ UfM Ministerial Conference, Progress report, 2016).

To analyze this case, the Global Gender Gap Index by World Economic Forum, was chosen as it focuses on gender gaps in such areas like economic, education, health and political criteria. This particular index considers such variables as female labour force ratio, literacy ratio, life expectancy value or number of females at the ministerial level or in parliament and other (The Global Gender Gap Report 2017).

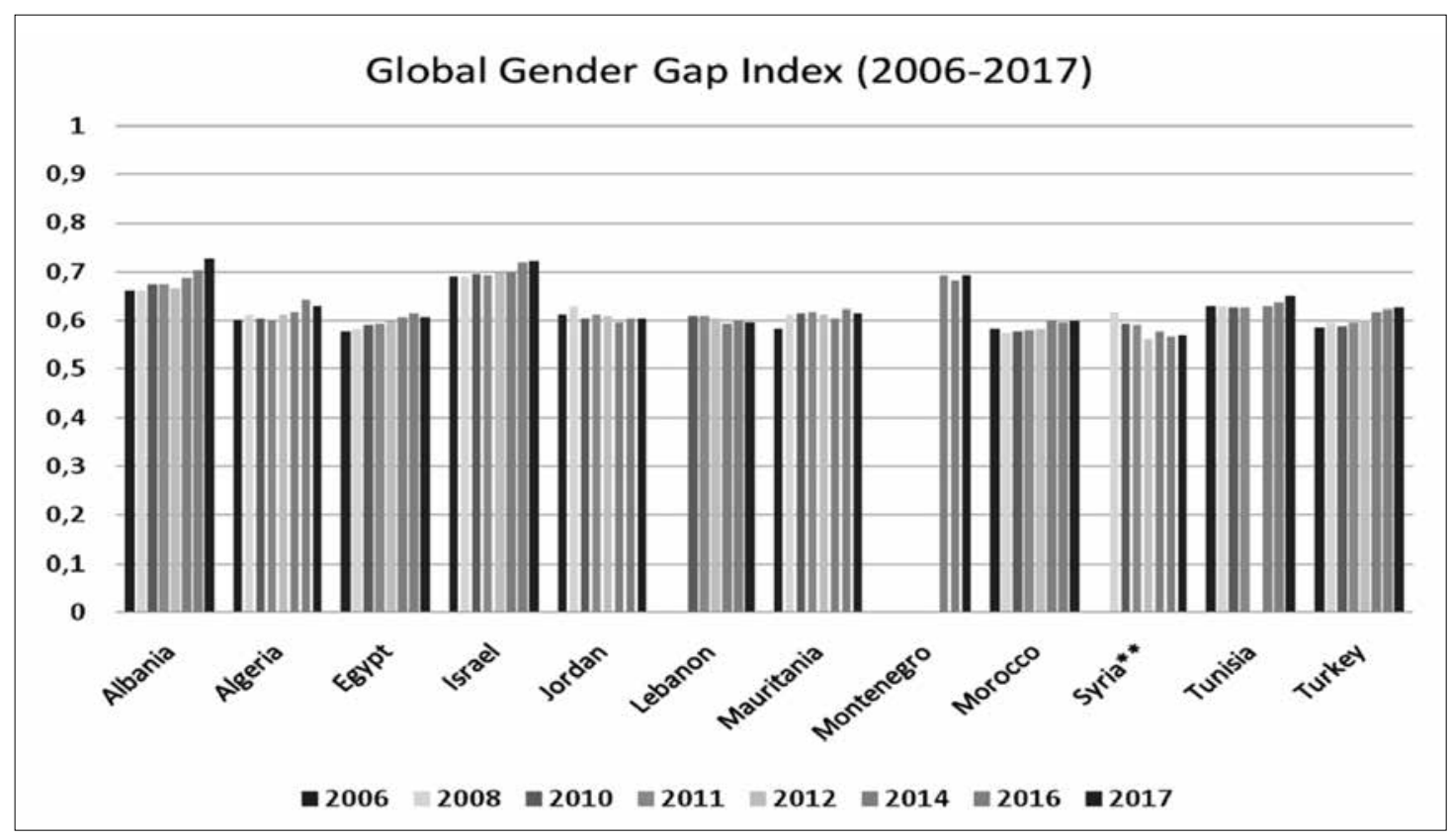

Figure 11. Global Gender Gap Index (2006-2017) (1=equality), made by the authors based on the World Economic Forum data 
As it is apparent from the result of the Global Gender Gap Index (Figure 11), no general tendency conclusion could be assumed as the development is very distinct in every country. This again only proves the statement of one of the interview respondents from the European Commission Representation in Lithuania that every Mediterranean country is developing by its own scenario. However, some improvements are still evident, as, for example, Albania, Algeria, Egypt, Israel or Turkey. And if to look at the point where most of these countries started improving, it would be around 2012, it could be tied to the Arab spring consequences.

Apart from the human development, the EU politics, Euro-Med initiatives have put much of efforts towards the Mediterranean environmental issues, seeking for a higher level of sustainability, environmental protection, pollution prevention and better water resource management. The UfM initiatives directed to improving these sectors were underlined as of a great importance also during some interviews: "Another thing why the UfM is of a great importance is its projects which are beneficial for everyone $\langle\ldots>$. The cooperation and efforts put in such fields like $\langle\ldots>$ environment $\langle\ldots>$ are mutual as they more or less equally affect both the EU and the southern Mediterranean countries. The question whether it is financially beneficial is not correct as not always we can measure the gains. For example, the environment protection, I believe, is not measurable, however, everybody understands that it is beneficial for all of us" (Interview with a representative of the Ministry of Foreign Affairs of Republic of Lithuania).

Having in mind that the environmental protection is sometimes hardly measurable but at the same time the more efforts given are always understood as a positive change, the amount of climate funding for the Mediterranean region could be considered since, according to OECD, tracking the climate finance is one of the essential elements in monitoring the progress of efforts addressed to climate change (OECD, Tracking Private Climate Finance, 2014).

The Mediterranean region receives rather impressive funding for the climate change agenda. Climate finance study shows that the UfM initiatives accounts approximately $11 \%$ of worldwide funding (Climate Finance Study, 2016) for climate change, thus, holding a big share of responsibility in this area.

The environmental and climate issues are a bigger threat to more of the areas that just environment as, according to the representative of the European Commission Representation in Lithuania, another big wave of migrants from the Southern region could occur precisely due to the climate change that cause poorer and poorer harvest every year and leading to more humanitarian issues or border security challenges. Therefore, any kind of efforts in this area could be evaluated rather as positive.

\section{Conclusions and discussion}

The secondary quantitative data analysis conducted above clearly shows that despite some minor improvements in the main areas of initiatives, all frameworks of the Euro-Mediterranean relations are far from reaching the initially set goals (especially concerning the political goals). As the UfM was an upgrade for the old Barcelona Process, it was supposed to better encounter the challenges of the partnership. Unfortunately, as it is evident in the analysis of this research, the Union for the Mediterranean does not live up to the expectations of 2008 and the areas denominated as priority do not show any significant result. There are some positive trends in very specific sectoral areas (concerning human development, women inclusion, or climate agenda) or as an outcome of projects implemented but no major institutional change (in socio-political systems) was noted.

Some respondents highlighted that existing cooperation in the context of the complex regional problems is a positive achievement per se. However, from the point of historical institutionalism one might ask why such a long "path" (over two decades) of Euro-Med partnership did not produce the desired institutional impact? The EU has applied bilateral and multilateral frameworks, multi - level cooperation including parliamentary and civil society dimensions, committees and regional forums- whole structure of institutions quite similar to the one, established within EU but this try of institutional reproduction did not root in the Mediterranean. So, the question remains what are the other ways, if any, to make institutional impact in the countries, whereas Europeanisation is not a primary desire. 


\section{References}

Abis S., Petiot A., Semerari F. (2015). Barcelona +20: Extinction or a New Lease of Life? Mediterranean Yearbook, p.112-116, European Institute of the Mediterranean, Girona.

Attiná F. (2004). The Barcelona Process, The Role Of The European Union And The Lesson Of The Western Mediterranean, The Journal of North African Studies 9(2): 140-152.

$20^{\text {th }}$ Anniversary of The Barcelona Process, November (2015). European Institute of the Mediterranean, http://www.iemed.org/actualitaten/noticies/20e-aniversari-del-proces-de-barcelona

Barcelona Declaration. (1995). Adopted in the Euro-Mediterranean Conference, Barcelona, https://ec.europa.eu/research/iscp/pdf/ policy/barcelona_declaration.pdf

Climate Finance Study, Overview (2016). UfM, 2017, http://ufmsecretariat.org/wp-content/uploads/2018/02/Climate-Finance-StudyDEF-web.pdf

Communication from the Commission of the European Parliament and the Council. (2008). Barcelona Process: Union for the Mediterranean, COM (2008) 319 final, May 2008, Brussels

Gadi S., Ayadi R. (2011). The Future Of Euro-Mediterranean Regional Cooperation: The Role of the Union for Mediterranean, 7 Papers IEMed joint series with EuroMeSCo, European Institute of the Mediterranean

Gorges-Michael J. (2001). The New Institutionalism and the Study of the European Union: The Case Of The Social Dialogue, West European Politics, 24(4): 152-168

Hattar, K. (2017). Middle East and North Africa: A very Drastic Decline, Transparency international, January, https://www.transparency. org/news/feature/mena_a_very_drastic_decline

Human Development Data (1995-2015), UN Development Programme, http://hdr.undp.org/en/data

Kisel'áková, D.; Šofranková, B.; Čabinová, V.; Onuferová, E. 2018. Competitiveness and sustainable growth analysis of the EU countries with the use of Global Indexes' methodology, Entrepreneurship and Sustainability Issues 5(3): 581-599. https://doi.org/10.9770/ jesi.2018.5.3(13)

Koelble-Thomas A. (1995). The New Institutionalism in Political Science and Sociology, Comparative Politics 27(2): 231-243

Lecours, A. (2005). New Institutionalism: Issues and Questions, New Institutionalism: Theory and Analysis, University of Toronto Press, 3-25

Tolvaišis, L. (2012). Political Parties and Ethnic Minority Policies, 1991-2011: A Comparative Study of Serbia's Hungarians and Estonia's Russians, Doctoral dissertation, Vytautas Magnus University

Med4Jobs, Creating Job Opportunities, Promoting Inclusive Growth, UfM Secretariat, December 2016, http://ufmsecretariat.org/wpcontent/uploads/2017/02/10_UfM-Med4Jobs-Leaflet-EN_web_final.pdf

Manners, I. (2006). The symbolic manifestation of the EU's normative role in world politics in Elgstrom O. and Smith M. (editors) The European Union's roles in international politics: concepts and analysis. Taylor \&Francis group, p.66-84

March- James G., Olsen- Johan P. (1984). The New Institutionalism: Organizational Factors In Political Life, The American Political Science Review 78(3): 734-749

Ross, S. (2016). 3 Financial Crises In The $21^{\text {st }}$ Century, Investopedia, January, https://www.investopedia.com/articles/investing/011116/3financial-crises-21st-century.asp

Passerini P., Biedma L. (2002). EU trade and investment with Mediterranean Partner Countries: towards a better partnership? Statistics in Focus, Economy and Finance, Theme 2-13, European Communities, http://ec.europa.eu/eurostat/documents/3433488/5462007/KSNJ-02-013-EN.PDF/281e5f26-a4cd-437c-a761-b176dfe36df4?version=1.0

Pierson, P. (2000). Increasing Returns, Path Dependence and the Study of Politics, American Political Science Review 94: $251-267$

Pierson P. and Russell Sage Foundation. (1994). The Path to European integration: a historical institutionalist perspective, Program for the study of Germany and Europe Working paper No.5.2, October 25. http://aei.pitt.edu/63633/1/PSGE_WP5_2.pdf

Pollack- Mark A. (1996). The New Institutionalism and EC Governance: The Promise and Limits of Institutional Analysis, Governance, 


\section{9: $429-458$}

Rabi, U. (2015). Analysis: The $21^{\text {st }}$ Century Middle East, The Jerusalem Post, June, http://www.jpost.com/Middle-East/The-21stcentury-Middle-East-407147

Radwan, A. (2018) Science and innovation policies in North African Countries: Exploring challenges and opportunities, Entrepreneurship and Sustainability Issues 6(1): 268-282. doi: 10.9770/jesi.2018.6.1(17)

Schlumberger O. (2011). The Ties That Do Not Bind: The Union for the Mediterranean and the Future of Euro-Arab Relations, Mediterranean Politics, 16: 135-153

The Global Gender Gap Report. (2017). World Economic Forum, http://www3.weforum.org/docs/WEF_GGGR_2017.pdf

Technical Notes, Human Development Report. (2015), http://hdr.undp.org/sites/default/files/hdr2016_technical_notes.pdf

Theories of European Integration, CIVITAS Institute for the Study of Civil Society. (2015). http://www.civitas.org.uk/content/files/ OS.16-Theories.pdf

The Economist Intelligence Unit's Democracy Index results 2006-2017, scale 0-1 authoritarian regimes, 4-6 hybrid regimes, 6-8 flawed democracy, 8-10 full democracy, https://infographics.economist.com/2018/DemocracyIndex/

Timeline:TheMiddleEastConflict,AlJazeera, January2008,http://www.aljazeera.com/news/middleeast/2007/09/200852519252884626. html

Tracking Private Climate Finance, Research Collaborative, OECD, http://www.oecd.org/env/researchcollaborative/

UfM Roadmap for Action. (2017). Adopted in Barcelona, January, http://ufmsecretariat.org/wp-content/uploads/2017/10/UfMRoadmap-for-action-2017.pdf

$4^{\text {th }}$ UfM Ministerial Conference on Strengthening the Role of Women. (2016). Progress Report, http://ufmsecretariat.org/wp-content/ uploads/2017/12/UfM_progress_report2016.pdf

Interview with the representative of Lithuanian Ministry for foreign affairs (2018)

Interview with the representative of the European Commission (2018)

Interview with the representative of the European Parliament delegation for the Parliamentary Assembly of the Union for Mediterranean (2018)

Interview with a member of European Parliament (2018)

\section{About authors}

Dr. Sima Rakutienè is a Vice-Dean and lecturer of political science at the Faculty of Political science and diplomacy of Vytautas Magnus University in Lithuania. She received $\mathrm{PhD}$ in political science focusing on European studies and international relations, her research interests include European integration, EU institutions, international institutions, regional cooperation, she is an author of over 20 publications mainly in European external relations field.

Roberta Paškevičiūtė received a Masters' degree in political science from Vytautas Magnus University, Diplomacy and International relations Masters' degree program, her research interests focus on Mediterranean studies and politics. 